\section{THE WHTECHAPEL TRAGEDY :}

NOTES OF A REPORT TO TIE SOLICITOR TO THE TREASURY ON THE POST MORTEA ENMMINATION OF THE RHMANS.

BY THOMAS' BOND, F.R.C.S.,

Assistant-Surgen to the Westminster Hospital, and Lecturer on Forensic Medicine.

50, Parliament sitreet, S. W., Sept. I6th.

SiR,-Accorting to your request, I beg to report that I received this day from Inspector Fox the remains of a human body in a sealed coffin. I received, also, from Dr. Larkin, the pelvic viscera of the same body in a closed jar. The body was divided into ten pieces; and, when fitted togrether, proved to be the complete body of an adult female, in an advanced stage of decomposition. The length of the body was just under five feet. The woman had evidently been dead many months; but certain parts were well preserved where they had been exposed, apparently, to the action of chloride of lime. The division of the body was undoubtedly of recent date, as proved by freshly cut bone and muscle. The division appeared to have been accomplished in an unskilful and bungling manner, by an adze or chopper, and was probably done by the hatchet in possession of the police.

The face was decomposed, and all trace of features lost. The scalp was partially separated from the skull, especially on the right side; and, attached to it, was a quantity of curly auburn hair at the back, fixed with hair-pins to a pad ; and, on the left side of the head, clotted with a dark substance resembling dried blood. The sutures of the skull were very distinct, with the exception of the frontal, which was obliterated. On the right side of the head, at the junction of the inferior and posterior angle of the parietal bone with the squamous p rrtion of the temporal, there was a depressed fracture, of the size of a sixpence; and, at the back part of the depressed bone, there was complete penetration of the skull by a hole large enough to admit a small bean. The fracture must have been caused by a hard blunt substance striking in a direction obliquely backwards and inwards. The fracture was not of recent date, the broken surface being of a dark colour, and similar in appearance to the exposed portion of the skull. The scalp was detached over the fracture and around for a distance approximately of three inches, exposing the skull. There was a penetrating wound of the scalp, which, when drawn forward, corresponded to a point on a level with, but an inch posterior to, the fracture. The scalp around the wound was dark-coloured, and its substance infiltrated with blood to a depth of one-sixteenth of an inch on its under surface. The uninjured portion of the scalp was of a pale brown colour.

The dura mater was detached from the skull-cap, and entire at the upper part, and of a light grey colour; but exactly opposite the fracture it was torn through, and of a dark brown colour around the puncture, from infiltrated blood. The above injuries were, I have no doubt, inflicted cluring life. On passing my finger into the hole in the dura mater, I found two spicula of bone. On opening the dura mater and removing the decomposed brain, I found a flattened bullet lying in the left hemispliere of the cerebellum, and in the direct axis of the hole through the skull. This bullet, I have no doubt, caused the injuries I have described. On removing the dura mater and the soft pulpy brain-substance, I discovered a second bullet lying on the posterior clinoid processes of the sphenoid bone. This bullet was flattened on the top only, and appeared to have entered the skull by direct impact. Both spinous processes were fractured; and, on further examination, I found a hole in the skull exactly above the base of the zygomatic process of the right temporal bone, passing directly inwards along the base of the brain, in a line with the petrous portion of the temporal bone, to the position of the bullet on the sphenoid bone. In the substance of the brain, and in the axis of the wound, I found a large spiculum of bone, but observed no effused blood. I cannot say if this wound was inflicted during life; but, if so, it was sufficient to cause leath.

The head was severed from the trunk between the sixth and serenth cervical vertebrac. A cut two inches long extended from the angle of the thyroid cartilage upwards to the left angle of the lower jaw, dividing the tissues down to the vertebre. The surface of the wound was retracted and dried, and not flaccid and soft like the cuts separating the body. It must have been inflicted from the front upwards and backwards. At the bottom of the wound, there was a cut nearly dividing the body of the third cervical vertebra. I am of opinion that the wound was inflicted during life, or directly after death; but cannot say positively, as the cut in the vertebra appeared to have been done recently. The hair over the left ear was much clotted with a suinstance like dried blood.

The teeth remaining in the jaws were perfect, with the exception of the first bicuspid of the right upper jaw, which was decayed to the root. The third molar of the upper jaw on the left side was still uncut. Four teeth were missing, having fallen out since death. The cartilages of the ribs were not ossified, and the bones of the skeleton were light and small. The cartilaginous ends of the bones were abunciantly covered with articular cartilage. I am of opinion that the age of deceased was from twenty to twenty-five years.

I examined the uterus, which was much decomposed, and found the cavity large, but the walls thin; the os was transverse and broad, and the neck projected very little into the vagina. In my opinion, the deceased had borne children.

THOMAS BOND, F.R.C.S.

September 24th.-I re-examined the remains, by request of solicitor for the defence, in the presence of Mr. Aubin, who attended on behalf of the prisoner. It had been stated by Mr. Lane that his daughter had a scar on one of her legs, but he could not recollect on which one. I, therefore, examined each leg very carefully ; scraping away the chloride of lime and earth which thickly covered most of the body. I first scraped the left leg completely, but discovered nothing except eroded patches on the skin, one of which Mr. Aubin cut out subsequently, under the impression that it was a scar. On scraping the right leg, I found an undoubted scar, exactly over the fibula, about four inches below the point of the knee. It was about the size of a shilling rather elongated, downwards and backwards. It was a hard fibrous scar, and one-eighth of an inch in depth. In front, the skin was healthy, but very much puckered; at the back, the skin was white, similar to the ordinary appearance found around the scar of a burn or scald. The epiphyses of the shoulder, thigh, and knee-joints, had united.

\section{ON INFUSION OF MATICO AS AN IN'TRA- UTERINE INJECTION.}

By W. D R A P E R, M.R.C.S., Sc., Surgeon to the York Dispensary.

In the Britisir Medical Journal of November $13^{\text {th }}$, Dr. Spender of Bath has note on infusion of matico as an intra-uterine injection in cases of uterine hæmorrhage. Dr. Spender asks whether: such an injection "has ever been tried in post partum hæmorrhage". In I868, I published, in the BRITISH MEDICAL JOURNAL, some cases of hxmorrhage treated by intra-uterine injection; and I then mentioned strong infusion of matico as having been employed by me. Again, as recently as July of last year, I communicated to the Obstetrical fournal, a paper on intra-uterine injection in hæmorrhage. In this paper, a case, illustrating the use of infusion of matico as a styptic injection, was given. Some years ago, when, as resident obstetric officer to. the Middlesex Hospital, I had ample opportunity for testing the relative value of different forms of intra-uterine injections, I gave infusion of matico a fair trial ; but, after due observation of its action in several cases of post partum hæmorrhage, of which cases, unfortunately, I have no record beyond that which my memory retains, I could not consider it, or, indeed, any other injection which I tried, so prompt and decided in action as the solution of perchloride of iron, used after Dr. Barnes's method. In other forms of uterine hæmorrhage, I found strong infusion of matico a valuable hæmostatic.

I can hardly think with Dr. Spender that, in the use of intra-uterine. injection, it is sufficient to inject the fluids into the vagina; for, although I do not deny that, when both the internal and external os uteri happen to be very patent, some fluid may find its way into the cavity of the uterus, still I think that one could hardly rely upon sufficient entering to act with certainty. The plan I have usually adopted in cases not connected with the puerperal state, has been to pass into the uterus a small silver tube perforated in all directions, and having a little plate at its proximal extremity. The plate prevents the tube from passing too far into the cavity of the uterus, and it also acts as a rest for the directing finger. This small tube is fixed to one end of a gum. elastic catheter, to the other end of which an elastic bottle is attached. This simple little apparatus has always answered satisfactorily. I may here repeat what I have recorded in previous communications, that I have never experienced any accident from the use of iron injections; but in their use in post partum hæmorrhage, as Dr. Barnes has recently observed, it is highly essential to preserve a passage by the side of the injecting tube, sufficient to allow the free outflow of the injected fluid from the uterine cavity. 